\title{
THE SCALE OF PRIORITY FOR THE CONSTRUCTION OF IRRIGATION CHANNELS FOR STAKEHOLDERS PERCEPTIONS OF THE IRRIGATION SERVICE IN SIDOARJO REGENCY
}

\author{
George Winaktu ${ }^{1}$, Lalu Mulyadi ${ }^{2}$, Edi Hargono DP ${ }^{3}$ \\ ${ }^{1}$ Civil Engineering Department, University of Islamic Malang, Malang, 65144, Indonesia. \\ ${ }^{2}$ Civil Engineering Construction Management Concentration, National Institute of Technology \\ Malang, Malang, 65145, Indonesia. \\ ${ }^{3}$ Civil Engineering Construction Management Concentration, National Institute of Technology \\ Malang, Malang, 65145, Indonesia. \\ E-mail: gewinaktu@gmail.com
}

\begin{abstract}
Sidoarjo Regency is one of the megapolitan Gerbang Kertosusilo. The planted area during the rainy season and dry season reaches $30,000 \mathrm{ha}$. The area of paddy fields continues to decline, namely 26,334 ha (2002), 22,460 ha (2010), and an estimated 13,544 ha (20092029). Sidoarjo Regency Irrigation Service as executor of irrigation management is of course inseparable from construction project activities. In the implementation of the construction of new irrigation networks as well as in rehabilitation and maintenance, it is necessary to implement project management. Before the project is implemented, it must first be submitted through proposals from the village level. In following up the proposal the writer used the Analytic Hierarchy Process (AHP) analysis method. With four aspects that affect the determination of the proposal: The results of the analysis obtained the weight of each criterion as follows: Service Area (ha) 0.3179, Cost 0.3159, Benefits 0.3217, and Network Conditions 0.0445 . The results of the above analysis obtained priority ranking from the first to the last sequence as follows: Plengsengan Gedangrowo Channel, Normalization of Reform Channels, Installation of floodgates, Plengsengan ChannelsDs. Suwaluh, Rehabilitation of Ketawang Canal Kec. Sukodono, Rehabilitation of Candi Subdistrict Channel, Plengsengan Channel Ds. Suwaluh, Plengsengan Channels Purboyo II Ds. Popoh, Plengsengan Irrigation Channels Dsn. Kesimbuk, Plengsengan Channel Mangetan Kanal.
\end{abstract}

Keywords: Analytic Hierarchy Process (AHP), Weight, Irrigation, Priority Scale

\section{Introduction}

Sidoarjo Regency is one of the megapolitan Gerbang Kertosusilo. LP2B is implicitly stipulated by Perda No. 6/2009 concerning RTRW 2009-2029 (Sidoarjo Regency Government, 2009). The RTRW Perda states that LP2B is set at 13,000 ha with a potential land area of 22,000 ha, consisting of 5,000 ha of sugarcane and 17,000 ha of rice. The planted area during the rainy season and dry season reaches $30,000 \mathrm{ha}$. The area of paddy fields continues to decline, namely 26,334 ha (2002), 22,460 ha (2010), and an estimated 13,544 ha (2009-2029).

The increasingly limited and competitive availability of water resources will not only have a negative effect on socio-economic life and among users in a sector. The dominant level of water demand outside the agricultural sector is to meet household and industrial consumption, which tends to increase in line with economic progress.

According to Rahman (1999), irrigation management is an effort to distribute water fairly and evenly, but the mechanism is often faced with several fundamental problems, namely: 1) the number of water group areas increases uncontrollably, 2) the relative location of the plot of rice fields from 
the channel is not taken into account. in water distribution and technology advice which is in the downstream (tail end), 3) illegal water tapping on the way continues without any variation between upstream and downstream parts. If we look at this problem, it is inseparable from institutional elements and policy instruments that have not functioned effectively in an effort to make people aware of the importance of water management.

Irrigation is very important in supporting food security, especially national rice production. Therefore, the central government, through the Office of Public Works for Irrigation, Sidoarjo Regency, annually receives APBD funds to be used in the rehabilitation and maintenance of the existing irrigation network system in Sidoarjo Regency. From year to year, the given budget continues to increase in order to support the food self-sufficiency program that has been launched by the central government. On the other hand, these offices are also required to absorb the budget according to the achievement targets set in the DPA each year. http://pupengairan.sidoarjokab.go.id/tugas-pokok-dan-fungsi/

In the implementation of the construction of new irrigation networks as well as rehabilitation and maintenance of irrigation network systems, project management is very necessary to be implemented. Project initiation starts with a need and goes up to the implementation stage. Before the project is implemented, a project proposal is first carried out. The proposal of a project is the result of selection from the number of needs that must be realized and in selecting a project proposal there are many factors that must be considered so that in its implementation it can minimize all risks that can hinder work in the field.

Criteria for the Regional Medium Term Development Plan (RPJMD) of Sidoarjo Regency in 2010-2015, subscribers to the irrigation network currently number 318 location points, while several programs have been launched, namely: maintenance, normalization, construction of dam gates and construction of plengsengan.

In following up on these proposals, so far there has not been an accurate method used, so that there are often inaccuracies. Therefore, in this study using the analytic hierarchy process (AHP) method in determining the appropriate priority scale for handling irrigation networks and careful calculations, so that goals can be achieved and do not reduce the quality of work.

Based on the background above, it can be formulated as follows: 1.How big is the weight of each of the criteria for the Determination of the Priority Scale of the Irrigation Canal Construction Project in Sidoarjo Regency Irrigation Service. 2.How big is the weight of each activity against the criteria for determining the priority scale of the Irrigation Service Irrigation Service Development Project in Sidoarjo Regency? What is the priority ranking for each activity to determine the Priority Scale for the Irrigation Canal Construction Project for the Irrigation Service of Sidoarjo Regency.

\section{Material and Methods}

The methodology used in this research includes literature review and study, data collection, preparation and application of the Analytical Hierarchy Process decision model. The sample in this study was taken as many as 20 respondents consisting of expertists as follows:

Table 1. Respondent

\begin{tabular}{ll}
\hline No & \multicolumn{1}{c}{ Respondents Information } \\
\hline $\mathbf{1}$ & $\begin{array}{l}\text { Head of the Sidoarjo Regency Public Works Service (drainage and irrigation expert) } \\
\text { Kasubdin Pengairan Dinas PU Sidoarjo Regency (expert in drainage and irrigation) }\end{array}$ \\
$\mathbf{2}$ & $\begin{array}{l}\text { Head of O\&P Irrigation Section of Sidoarjo Regency Public Works Office (expert in } \\
\text { drainage and irrigation) }\end{array}$ \\
$\mathbf{3}$ & $\begin{array}{l}\text { Consultant (drainage expert) } \\
\text { Kasie O \& P Pengairan Dinas PU Kabupaten Sidoarjo(expertis drainase dan irigasi) }\end{array}$ \\
$\mathbf{4}$ & Konsultan (expertis drainase)
\end{tabular}

Source: Processed Results 
Analytical Hierarchy Process (AHP) is used to determine strategic alternatives according to the determining factors. The following are the steps in the AHP method (Saaty, 1991):

1. Define the problem and determine the desired solution.

2. Creating a hierarchical structure starting with a general objective, followed by subobjectives, criteria and possible alternatives at the lowest level of criteria.

3. Creating a pairwise comparison matrix that describes the relative contribution or influence of each element to each goal or criteria that are a level above it. Comparisons are made based on the judgment of the decision maker by assessing the importance of an element compared to other elements.

4. Perform pairwise comparisons, starting from the top level of the hierarchy aimed at selecting criteria, for example $\mathrm{X}$, then the elements to be compared are taken, for example X1, X2, and X3. Thus, the arrangement of the elements being compared will look like in Table 2 .

The determination of the relative importance value between elements uses a scale of 1 to 9 as in Table 3. If an element is compared to itself it is given a value of 1 . If element $i$ is compared to element $j$ gets a certain value, then element $j$ is compared to element $i$ is the opposite.

5. Calculating the eigenvalues and testing the consistency, if not consistent data collection is repeated.

6. Repeat steps 3,4, and 5 for all levels of the hierarchy.

7. Calculate the eigenvectors of each pairwise comparison matrix. The eigenvector value is the weight of each element. This step is to synthesize judgment in determining the priority of elements at the lowest hierarchical level until the achievement of goals.

8. Checking the consistency of the hierarchy, if the score is less than 10 percent then the judgment is accepted.

9. Check hierarchy consistency. If the value is more than 10 percent, the judgment data assessment must be corrected.

Table 2. Example of Pairwise Comparison Matrix

\begin{tabular}{cccc}
\hline FACTORS & $\mathbf{X 1}$ & $\mathbf{X 2}$ & $\mathbf{X 3}$ \\
\hline $\mathbf{X} 1$ & 1 & 2 & 5 \\
\hline $\mathbf{X} 2$ & $1 / 2$ & 1 & $1 / 4$ \\
\hline $\mathbf{X 3}$ & $1 / 5$ & 2 & 1 \\
\hline
\end{tabular}

Source: Processed Results

Table 3. AHP Rating Scale

\begin{tabular}{ll}
\hline Value & \multicolumn{1}{c}{ Description } \\
\hline $\mathbf{1}$ & Criterion / alternative A is as important as criterion / alternative B \\
\hline $\mathbf{3}$ & Criterion / alternative A is slightly more important than criterion / alternative \\
\hline $\mathbf{5}$ & A clear criterion / alternative A is more important than criterion / alternative \\
\hline $\mathbf{7}$ & Criterion / alternative A is clearly more important than criterion / alternative \\
\hline $\mathbf{9}$ & Criterion / alternative A is absolutely more important than criterion / \\
\hline $\mathbf{2 , 4 , 6 , 8}$ & When in doubt between two adjacent values
\end{tabular}

Source: Processed Results 


\section{Result and Discussion}

\subsection{Criteria Weight Analysis Between Criteria}

In the AHP analysis process, the first step is to tabulate the results of respondents' answers using an Excel Template with multiple Inputs Klaus D. Goepel. (Attachment 1) Determination of variable priority values is done by making a paired comparison table of influence, namely, as follows:

Table 4. Criteria Comparison Matrix Between Criteria

\begin{tabular}{|c|c|c|c|c|}
\hline & $\begin{array}{l}\text { Service Area } \\
\text { (ha) }\end{array}$ & Cost & Benefit & $\begin{array}{l}\text { Network } \\
\text { Condition }\end{array}$ \\
\hline $\begin{array}{l}\text { Service Area } \\
\text { (ha) }\end{array}$ & 1 & 1 & 1 & 7 \\
\hline Cost & 1 & 1 & 1 & 6 \\
\hline Benefit & 1 & 1 & 1 & 9 \\
\hline $\begin{array}{l}\text { Network } \\
\text { Condition }\end{array}$ & $1 / 7$ & $1 / 6$ & $1 / 9$ & 1 \\
\hline
\end{tabular}

Source: Processed Results

Furthermore, to determine the weight of each criterion, a comparison of the criteria is used. The next step is to divide the value of each matrix element in appendix 1 by the number of each column. The quotient can be seen in:

Table 5. Criteria Weight Calculation Results

\begin{tabular}{lcc}
\hline \multicolumn{1}{c}{ Criteria } & Priority Weights & Rating \\
\hline Service Area (ha) & 0,3179 & 2 \\
\hline Cost & 0,3159 & 3 \\
\hline Benefit & 0,3217 & 1 \\
\hline Network Condition & 0,0445 & 4 \\
\hline
\end{tabular}

Source: Processed Results

So that the result is like table 4.2 the weight of the pairwise comparison criteria, then look for the Consistency Index (CI) value and the Consistency Ratio (CR) value according to the formula in the AHP method. The result is.

\begin{tabular}{|c|c|c|c|c|}
\hline C & $($ Lamda max $-n)$ & & I & $\mathbf{N}$ \\
\hline \multirow[t]{3}{*}{$\mathbf{I}$} & 4,0 & 4 & I & $4-1$ \\
\hline & $\mathbf{0 , 0}$ & & & \\
\hline & $\mathbf{0 , 0 0 8}$ & & & \\
\hline
\end{tabular}

Obtained the value of Consistency Index $(\mathrm{CI})=0.008$

\begin{tabular}{cccc}
\hline $\mathbf{C}$ & $\mathbf{C}$ & $/$ & $\mathbf{I}$ \\
\cline { 2 - 4 } $\mathbf{R}$ & $\mathbf{0 , 0 0 8}$ & $/$ & $\mathbf{0 , 9}$ \\
\cline { 2 - 4 } & $\mathbf{0 , 0 0 8 8}$ & & \\
\hline
\end{tabular}

The calculation results in the Consistency Ratio (CR) value of $0.0088 \leq 0.1$, then it is accepted. if the $\mathrm{CR}$ value is more than 0.1 then the $\mathrm{CR}$ is rejected. $\mathrm{IR}=0.9$, taken from the rules of the random index table that have been determined according to the size of the existing element matrix. $\mathrm{IR}=1.24$, taken from the rules of the random index table that have been determined according to the size of the existing element matrix. 


\subsection{Activity Weight Calculation}

In the AHP analysis process, the first step is to tabulate the results of respondents' answers using an Excel Template with multiple Inputs Klaus D. Goepel. (Attachment 1) Determination of variable priority values is done by making a paired comparison table of influence, namely, as follows:

Table 6. Alternative Activities

\begin{tabular}{ccl}
\hline No & Code & \multicolumn{1}{c}{ Activity } \\
\hline $\mathbf{1}$ & A1 & Plengsengan Channels Gedangrowo \\
\hline $\mathbf{2}$ & A2 & Normalization of Reform Channels \\
\hline $\mathbf{3}$ & A3 & Plengsengan Channels Gedangrowo \\
\hline $\mathbf{4}$ & A4 & Plengsengan Channels Ds. Suwaluh \\
\hline $\mathbf{5}$ & A5 & Plengsengan Channel Mangetan Kanal \\
\hline $\mathbf{6}$ & A6 & Plengsengan Irrigation Channel Dsn. Kesimbuk \\
\hline $\mathbf{7}$ & A7 & Plengsengan Saluran Purboyo II Ds. Popoh \\
\hline $\mathbf{8}$ & A8 & Rehabilitation of Candi Subdistrict Canal \\
\hline $\mathbf{9}$ & A9 & Rehabilitation of Candi Subdistrict Canal \\
\hline $\mathbf{1 0}$ & A10 & Installing the floodgates \\
\hline
\end{tabular}

Source: Processed Results

Table 7. Inter-Activity Comparison Matrix

\begin{tabular}{ccccccccccc}
\hline ACVTIVITY & A1 & $\mathbf{A 2}$ & $\mathbf{A 3}$ & $\mathbf{A 4}$ & $\mathbf{A 5}$ & $\mathbf{A 6}$ & $\mathbf{A 7}$ & $\mathbf{A 8}$ & $\mathbf{A 9}$ & $\mathbf{A 1 0}$ \\
\hline $\mathbf{A 1}$ & 1 & 9 & 1 & 7 & 4 & 1 & 8 & 1 & 5 & $1 / 5$ \\
\hline $\mathbf{A 2}$ & $1 / 9$ & 1 & $1 / 8$ & 6 & 8 & 5 & 9 & 7 & $1 / 5$ & 5 \\
\hline $\mathbf{A 3}$ & 1 & 8 & 1 & 9 & 1 & 1 & 1 & 1 & 5 & $1 / 5$ \\
\hline $\mathbf{A 4}$ & $1 / 7$ & $1 / 6$ & $1 / 9$ & 1 & 1 & 1 & 1 & 1 & 5 & 5 \\
\hline $\mathbf{A 5}$ & $1 / 4$ & $1 / 8$ & 1 & 1 & 1 & 1 & 1 & 1 & $1 / 5$ & 5 \\
\hline $\mathbf{A 6}$ & 1 & $1 / 5$ & 1 & 1 & 1 & 1 & 1 & 1 & $1 / 5$ & 5 \\
\hline $\mathbf{A} 7$ & $1 / 8$ & $1 / 9$ & 1 & 1 & 1 & 1 & 1 & 1 & 5 & 5 \\
\hline $\mathbf{A 8}$ & 1 & $1 / 7$ & 1 & 1 & 1 & 1 & 1 & 1 & 5 & 5 \\
\hline $\mathbf{A 9}$ & $1 / 5$ & 5 & $1 / 5$ & $1 / 5$ & 5 & 5 & $1 / 5$ & $1 / 5$ & 1 & 5 \\
\hline $\mathbf{A 1 0}$ & 5 & $1 / 5$ & 5 & $1 / 5$ & $1 / 5$ & $1 / 5$ & $1 / 5$ & $1 / 5$ & $1 / 5$ & 1 \\
\hline
\end{tabular}

Source: Processed Results

Furthermore, to determine the weight of each activity, the pairing comparison between activities is used.

Table 8. Inter-Activity Comparison Matrix

\begin{tabular}{|c|c|c|c|c|c|c|c|c|c|c|c|}
\hline & A1 & $\mathbf{A 2}$ & $\mathbf{A 3}$ & A4 & A5 & A6 & A7 & A8 & A9 & A10 & $\begin{array}{l}\text { Weight } \\
\text { Value }\end{array}$ \\
\hline A1 & 0,1984 & 0,1984 & 0,1983 & 0,1983 & 0,1983 & 0,1983 & 0,1983 & 0,1983 & 0,1983 & 0,1983 & 0,1983 \\
\hline A2 & 0,1644 & 0,1644 & 0,1644 & 0,1644 & 0,1644 & 0,1645 & 0,1644 & 0,1645 & 0,1644 & 0,1644 & 0,1644 \\
\hline A3 & 0,1127 & 0,1127 & 0,1127 & 0,1127 & 0,1127 & 0,1127 & 0,1127 & 0,1127 & 0,1127 & 0,1127 & 0,1127 \\
\hline A4 & 0,0896 & 0,0896 & 0,0896 & 0,0896 & 0,0896 & 0,0896 & 0,0896 & 0,0896 & 0,0896 & 0,0896 & 0,0896 \\
\hline A5 & 0,0831 & 0,0831 & 0,0831 & 0,0831 & 0,0831 & 0,0831 & 0,0831 & 0,0831 & 0,0831 & 0,0831 & 0,0831 \\
\hline A6 & 0,0715 & 0,0715 & 0,0715 & 0,0715 & 0,0715 & 0,0715 & 0,0715 & 0,0715 & 0,0715 & 0,0715 & 0,0715 \\
\hline A7 & 0,1154 & 0,1154 & 0,1154 & 0,1154 & 0,1154 & 0,1154 & 0,1154 & 0,1154 & 0,1154 & 0,1154 & 0,1154 \\
\hline A8 & 0,0979 & 0,0979 & 0,0979 & 0,0979 & 0,0979 & 0,0979 & 0,0979 & 0,0979 & 0,0979 & 0,0979 & 0,0979 \\
\hline A9 & 0,0281 & 0,0281 & 0,0281 & 0,0281 & 0,0281 & 0,0281 & 0,0281 & 0,0281 & 0,0281 & 0,0281 & 0,0281 \\
\hline A10 & 0,0389 & 0,0389 & 0,0389 & 0,0389 & 0,0389 & 0,0389 & 0,0389 & 0,0389 & 0,0389 & 0,0389 & 0,0389 \\
\hline
\end{tabular}

Source: Processed Results 
In the fourth iteration, the calculations are generated as in Table 3.5. where the pairwise multiplication ratio is close to zero so that it can be said that the calculation is sufficient to take the result.

Table 9. Activity Weight

\begin{tabular}{cclcc}
\hline No & Code & \multicolumn{1}{c}{ Activity } & Activity Weight \\
\hline $\mathbf{1}$ & A1 & Plengsengan Channels Gedangrowo & 0,1983 \\
\hline $\mathbf{2}$ & A2 & Normalization of Reform Channels & 0,1644 \\
\hline $\mathbf{3}$ & A3 & Plengsengan Channels Gedangrowo & 0,1127 \\
\hline $\mathbf{4}$ & A4 & Plengsengan Channels Ds. Suwaluh & 0,0896 \\
\hline $\mathbf{5}$ & A5 & Plengsengan Channel Mangetan Kanal & 0,0831 \\
\hline $\mathbf{6}$ & A6 & $\begin{array}{l}\text { Plengsengan Irrigation Channel Dsn. } \\
\text { Kesimbuk }\end{array}$ & 0,0715 \\
\hline $\mathbf{7}$ & A7 & Plengsengan Saluran Purboyo II Ds. Popoh & 0,1154 \\
\hline $\mathbf{8}$ & A8 & Plengsengan Channels Gedangrowo & 0,0979 \\
\hline $\mathbf{9}$ & A9 & Normalization of Reform Channels & 0,0281 \\
\hline $\mathbf{1 0}$ & A10 & Plengsengan Channels Gedangrowo & 0,0389 \\
\hline
\end{tabular}

Source: Processed Results

So that the resulting matrix such as table 3.6 activities with the highest weight A1 Plengsengan Gedangrowo Channel.

Looking for the Consistency Index (CI) value and the Consistency Ratio (CR) value according to the formula in the AHP method. The result is.

\begin{tabular}{lcccc}
\hline C & (Lamda max $-\mathbf{n})$ & & $/$ & $\mathbf{n}$ \\
\cline { 2 - 4 } $\mathbf{I}$ & $\mathbf{1 1 . 3 4}$ & 10 & $/$ & $\mathbf{1 0}-\mathbf{1}$ \\
\cline { 2 - 2 } & $\mathbf{1 . 3}$ & & \\
\hline & $\mathbf{0 , 1 5}$ & & & \\
\hline
\end{tabular}

The value of Consistency Index $(\mathrm{CI})=0.15$ was obtained

\begin{tabular}{llll}
\hline $\mathbf{C}$ & $\mathbf{C}$ & $/$ & $\mathbf{I}$ \\
\cline { 2 - 4 } $\mathbf{R}$ & $\mathbf{0 , 1 5}$ & $/$ & $\mathbf{1 , 5 1}$ \\
\cline { 2 - 4 } & $\mathbf{0 , 0 0 9 9}$ & & \\
\hline
\end{tabular}

The calculation results in the Consistency Ratio (CR) value of $0.099 \leq 0.1$, then it is accepted. if the $C R$ value is more than 0.1 then the $C R$ is rejected. $I R=1.51$, taken from the rules of the random index table that have been determined according to the size of the existing element matrix. $I R=1.51$, taken from the rules of the random index table that have been determined according to the size of the existing element matrix. 


\subsection{Results of the Analysis of Activity Priority Based on Criteria}

a. Result of Weight Calculation based on Area of Service

\begin{tabular}{|c|c|c|c|c|c|}
\hline Criteria & Weight & Activity & Weight & $\begin{array}{c}\text { Value weight } \\
\text { (criteria } x \text { activities) }\end{array}$ & Ranking \\
\hline \multirow[t]{10}{*}{ Service Area Area } & 0,19463 & A1 & 0,1670 & 0,03250 & 1 \\
\hline & & $\mathrm{A} 2$ & 0,1531 & 0,02980 & 2 \\
\hline & & A3 & 0,1130 & 0,02200 & 4 \\
\hline & & A4 & 0,0674 & 0,01312 & 7 \\
\hline & & A5 & 0,0524 & 0,01021 & 10 \\
\hline & & A6 & 0,0656 & 0,01277 & 9 \\
\hline & & A7 & 0,0668 & 0,01299 & 8 \\
\hline & & A8 & 0,0818 & 0,01592 & 6 \\
\hline & & A9 & 0,0927 & 0,01804 & 5 \\
\hline & & A10 & 0,1400 & 0,02726 & 3 \\
\hline
\end{tabular}

b. Calculation Results of Activity Weight Based on Cost

\begin{tabular}{|c|c|c|c|c|c|}
\hline Criteria & Weight & Activity & Weight & $\begin{array}{c}\text { Value weight } \\
\text { (criteria } x \text { activities) }\end{array}$ & Ranking \\
\hline \multirow[t]{10}{*}{ Cost } & 0,0041 & A1 & 0,1670 & 0,0007 & 1 \\
\hline & & $\mathrm{A} 2$ & 0,1531 & 0,0006 & 2 \\
\hline & & A3 & 0,1130 & 0,0005 & 4 \\
\hline & & A4 & 0,0674 & 0,0003 & 7 \\
\hline & & A5 & 0,0524 & 0,0002 & 10 \\
\hline & & A6 & 0,0656 & 0,0003 & 9 \\
\hline & & A7 & 0,0668 & 0,0003 & 8 \\
\hline & & A8 & 0,0818 & 0,0003 & 6 \\
\hline & & A9 & 0,0927 & 0,0004 & 5 \\
\hline & & A10 & 0,1400 & 0,0006 & 3 \\
\hline
\end{tabular}

c. Results of Calculation of Activity Weight by Benefits.

\begin{tabular}{lcrrrc}
\hline Criteria & Weight & Activity & Weight & $\begin{array}{c}\text { Value weight } \\
\text { (criteria x activities) }\end{array}$ & Ranking \\
\hline Benefits & 0,1956 & A1 & 0,1670 & 0,0327 & 1 \\
\hline & A2 & 0,1531 & 0,0300 & 2 \\
\hline & A3 & 0,1130 & 0,0221 & 4 \\
\hline & A4 & 0,0674 & 0,0132 & 7 \\
\hline & A5 & 0,0524 & 0,0103 & 10 \\
\hline & A6 & 0,0656 & 0,0128 & 9 \\
\hline & A7 & 0,0668 & 0,0131 & 8 \\
\hline & A8 & 0,0818 & 0,0160 & 6 \\
\hline & A9 & 0,0927 & 0,0181 & 5 \\
\hline & A10 & 0,1400 & 0,0274 & 3 \\
\hline
\end{tabular}


d. Calculation Results of Activity Weight Based on Network Conditions

\begin{tabular}{|c|c|c|c|c|c|}
\hline Criteria & Weight & Activity & Weight & $\begin{array}{c}\text { Value weight } \\
\text { (criteria } x \text { activities) }\end{array}$ & Ranking \\
\hline \multirow[t]{10}{*}{ Network Condition } & 0,00279 & A1 & 0,1670 & 0,0005 & 1 \\
\hline & & A2 & 0,1531 & 0,0004 & 2 \\
\hline & & A3 & 0,1130 & 0,0003 & 4 \\
\hline & & A4 & 0,0674 & 0,0002 & 7 \\
\hline & & A5 & 0,0524 & 0,0001 & 10 \\
\hline & & A6 & 0,0656 & 0,0002 & 9 \\
\hline & & A7 & 0,0668 & 0,0002 & 8 \\
\hline & & A8 & 0,0818 & 0,0002 & 6 \\
\hline & & A9 & 0,0927 & 0,0003 & 5 \\
\hline & & A10 & 0,1400 & 0,0004 & 3 \\
\hline
\end{tabular}

Table 10. Global Weighting Results

\begin{tabular}{ccccccc}
\hline & $\begin{array}{c}\text { Service Area } \\
\text { Area } \\
\mathbf{( 0 , 1 9 4 6 3 )}\end{array}$ & $\begin{array}{c}\text { Cost } \\
\mathbf{( 0 , 0 0 4 1 )}\end{array}$ & Benefit & $\begin{array}{c}\text { Condition } \\
\text { Network } \\
\mathbf{( 0 , 0 0 2 8 )}\end{array}$ & Weight & Ranking \\
\hline $\mathbf{A 1}$ & 0,0325 & 0,0007 & 0,0327 & 0,0005 & 0,0663 & 1 \\
\hline $\mathbf{A 2}$ & 0,0298 & 0,0006 & 0,0300 & 0,0004 & 0,0608 & 2 \\
\hline $\mathbf{A 3}$ & 0,0220 & 0,0005 & 0,0221 & 0,0003 & 0,0449 & 4 \\
\hline $\mathbf{A 4}$ & 0,0131 & 0,0003 & 0,0132 & 0,0002 & 0,0268 & 7 \\
\hline $\mathbf{A 5}$ & 0,0102 & 0,0002 & 0,0103 & 0,0001 & 0,0208 & 10 \\
\hline $\mathbf{A 6}$ & 0,0127 & 0,0003 & 0,0128 & 0,0002 & 0,0261 & 9 \\
\hline $\mathbf{A 7}$ & 0,0129 & 0,0003 & 0,0131 & 0,0002 & 0,0265 & 8 \\
\hline $\mathbf{A 8}$ & 0,0159 & 0,0003 & 0,0160 & 0,0002 & 0,0325 & 6 \\
\hline $\mathbf{A 9}$ & 0,0180 & 0,0004 & 0,0181 & 0,0003 & 0,0368 & 5 \\
\hline $\mathbf{A 1 0}$ & 0,0272 & 0,0006 & 0,0274 & 0,0004 & 0,0556 & 3 \\
\hline
\end{tabular}

From the calculation results, the global weighting value is obtained where the criteria have an influence on the priority determination of the irrigation project development activities of the Sidoarjo Regency Waterworks Office with the highest weight level of Plengsengan Gedangrowo Channel, the second is Reformation Channel Normalization.

Table 11. Activity Weighting Priority Ranking Results

\begin{tabular}{clc}
\hline $\begin{array}{c}\text { No. } \\
\text { Activities }\end{array}$ & \multicolumn{1}{c}{ Name of activity } & Ranking \\
\hline $\mathbf{A 1}$ & Plengsengan Channels & 1 \\
\hline $\mathbf{A 2}$ & $\begin{array}{l}\text { Gedangrowo } \\
\text { Normalization of Reform Channels }\end{array}$ & 2 \\
\hline $\mathbf{A 1 0}$ & Installing the floodgate & 3 \\
\hline $\mathbf{A 3}$ & Plengsengan Channels Ds. Suwaluh & 4 \\
\hline $\mathbf{A 9}$ & Rehabilitation of Ketawang Channel Kec. Sukodono & 5 \\
\hline $\mathbf{A 8}$ & Rehabilitation of Candi Subdistrict Canal & 6 \\
\hline
\end{tabular}




\begin{tabular}{clc}
\hline A4 & Plengsengan Channels Ds. Suwaluh & 7 \\
\hline A7 & Plengsengan Channels Purboyo II Ds. Popoh & 8 \\
\hline A6 & Plengsengan Irrigation Channel Dsn. Kesimbuk & 9 \\
\hline A5 & Plengsengan Channel Mangetan Kana & 10 \\
\hline
\end{tabular}

From the above calculations, the A1 or plengsengan channel Gedangrowo activity ranking is the first priority. The results of the AHP analysis of the priority scale for improvement of activities in irrigation network development explain that the benefits of irrigation networks. The results of the analysis are in line with the results of the analysis of consistency ratios. The results of the analysis of these methods indicate the validity of the priority scale of irrigation network development.

\section{Conclusions}

Based on the results of the analysis and discussion in the previous chapter, conclusions can be drawn:

1. The results of the analysis obtained the weight of each criterion as follows: Service Area (ha) 0.3179 , Cost 0.3159, Benefits 0.3217, and Network Conditions 0.0445 .

2. The results of the analysis obtained the weights for each activity as follows: Plengsengan Gedangrowo Channel with weight 0.1983 , Reformation Channel Normalization weight 0.1644 , Plengsengan Gedangrowo Channel weight 0.1127, Plengsengan Channel Ds.Suwaluh weight 0.0896, Plengsengan Channel Mangetan Kanal weight 0.0831, Plengsengan Irrigation Channel Dsn. Kesimbuk weight 0.0715, Plengsengan Canal Purboyo II Ds. Popoh weighs 0.1154, Rehabilitation of Candi Subdistrict Channels with a weight of 0.0979, Rehabilitation of Candi Subdistrict with a weight of 0.0281 , Installation of floodgates with a weight of 0.0389 .

3. The results of the above analysis obtained priority ranking from the first to the last sequence as follows: Plengsengan Gedangrowo Channel, Normalization of Reform Channels, Installation of floodgates, Plengsengan Ds. Suwaluh, Rehabilitation of Ketawang Canal Kec. Sukodono, Rehabilitation of Candi Subdistrict Channel, Plengsengan Channel Ds. Suwaluh, Plengsengan Channels Purboyo II Ds. Popoh, Plengsengan Irrigation Channels Dsn. Kesimbuk, Plengsengan Channel Mangetan Kanal.

For better results it is necessary to carry out further studies including: 1. AHP method is used for determining criteria and in making decisions. 2. This method can be used in activities related to costs and budgets.

\section{Acknowledgements}

We would like to thank all those who have helped in carrying out this research, especially the Head of the Sidoarjo Regency Water Works Department. The author thanks Prof. Dr. Ir Lalu Mulyadi MT and the Academic Community of the National Institute of Technology (ITN) Malang for their support in this research.

\section{References}

[1] DirJen DPU, Standar Perencanaan Irigasi (Kriteria Perencanaan Irigasi Bagian Penunjang). Direktorat Jenderal Pengairan Departemen Pekerjaan Umum. 1986

[2] DirJen DPU, Standar Perencanaan Irigasi (KP 01). Direktorat Jenderal Pengairan Departemen Pekerjaan Umum. 1986

DirJen DPU 2000, Irigasi Direktorat Jenderal Pengairan Departemen Pekerjaan Umum.

[3] DirJen DPU 2007, Indeks Kinerja Sistem Irigasi Dit.Irigasi Rawa Direktorat Jenderal Pengairan Departemen Pekerjaan Umum Montarcih Limantara,

Dumairy. Direktorat Pengelolaan Air, 2010 Pedoman Teknis Rehabilitasi Jaringan Tingkat Usahatani (JITUT)/Jaringan Irigasi Desa (JIDES). Direktorat Jenderal Pengelolaan Lahan dan Air, Departemen Pertanian. Jakarta, 1992 
[4] Hansen, V. Ekonomika Sumberdaya Air. BPPE. Yogyakarta. Hansen, V. 1986. Hayami, Y Development Economics: From the Poverty to the Wealth of Nations. Second Edition. Oxford University Press. New York. 2001.

[5] Isnaini Aliyansyah,dkk Jurnal, Identifikasi Faktor-Faktor Yang Dipertimbangkan Dalam Usulan Proyek Irigasi (Studi Kasus Pada Balai Wilayah Sungai Sumatera- I Aceh) Volume 1, No. 2, November 2012

[6] Mulyawati dkk, Jurnal Penentuan Prioritas Kegiatan Operasi Dan Pemeliharaan Daerah Irigasi Dengan Menggunakan Metoda Analytic Hierarchy Process (AHP) 2013.

[7] Perpu RI Peraturan Pemerintah Nomor 23 Tahun 1982 Tentang Irigasi.

[8] Peraturan Pemerintah Nomor 23 Tahun 1982 Tentang Irigasi

Rachman. B, Analisis kelembagaan Jaringan Tata Air dalam Meningkatkan Efisiensi dan Optimasi Alokasi Penyaluran Air Irigasi di Wilayah Pengembangan IP. 300, Jawa Barat. PPS-IPB, Bogor, 1999.

[9] Saaty. T.L., Pengambilan Keputusan Bagi Para Pemimpin, Proses Hirarki Analitik untuk Pengambilan Keputusan dalam Situasi yang Kompleks, Pustaka Binama Pressindo, Jakarta. 1993.

[10] Supriyono Dkk , Jurnal Studi Penentuan Skala Prioritas Berdasarkan Kinerja Jaringan Irigasi Pada Jaringan Irigasi Batujai, Gde Bongoh, Dan Sidemen Di Kabupaten Lombok Tengah, 2010. 